\title{
IMPLEMENTATION OF STAD LEARNING MODELS TO IMPROVE 5th STUDENTS' CRITICAL THINKING SKILLS AND MATHEMATICS LEARNING OUTCOMES
}

\author{
Diah Edwin Gustia $^{1)}$; Mawardi ${ }^{2)}$ dan Suhandi Astuti ${ }^{3)}$ \\ 1,2,3 Pendidikan Guru Sekolah Dasar, Universitas Kristen Satya Wacana \\ Email: 292015142@ @student.uksw.edu ${ }^{1}$; Email: mawardi@ staff.uksw.edu $^{2}$; \\ Email: Suhandiastuti15@gmail.com ${ }^{3}$
}

\begin{abstract}
This study is aims to improve critical thinking skills and mathematics learning outcomes of 5 th grade students using the STAD (Students Team Achievement Division) instructional model. This research used was Classroom Action Research, with two cycles. The subjects of this study is 31 fifth grade students of SDN Tingkir Lor Salatiga. The instrument used was the critical thinking questionnaire and 15 items test. The results showed that the STAD instructional model can improve critical thinking skills and student learning outcomes. Improved of critical thinking skills can be seen from the average score in cycle I of 58, in the sufficient category, then increased to 77 in the high category in cycle II. Improved of learning outcomes can be seen from the acquisition of scores in the first cycle of 66, with a percentage of learning completeness of $61 \%$, increasing to 80 , with the percentage of learning completeness reaching $84 \%$ ini cycle II.
\end{abstract}

Keywords: Critical thinking, Mathematics learning outcomes, STAD models.

\section{PENDAHULUAN}

Kajian tentang matematika merupakan kajian yang menjadi muatan pada semua jenjang pendidikan, mulai dari tingkat sekolah dasar hingga perguruan tinggi. Bahkan matematika diajarkan di taman kanak-kanak secara informal (Susanto, 2013: 183). Berkaitan dengan isi muatan matematika, Permendikbud No. 24 Tahun 2016 tentang Kompetensi Inti dan Kompetensi Dasar, menyatakan bahwa isi muatan atau ruang lingkup matematika mencakup bilangan; geometri; dan statistika (Kemendikbud, 2016: 111-112). Ketentuan lain dalam Permendikbud No. 21 Tahun 2016 tentang Standar Isi Pendidikan Dasar dan Menengah, dinyatakan bahwa salah satu kompetensi yang ingin dicapai oleh matematika di tingkat pendidikan, khususnya pada tingkat pendidikan dasar adalah menunjukkan sikap positif bermatematika, seperti logis, cermat dan teliti, jujur, bertanggung jawab, dan tidak mudah menyerah dalam menyelesaikan masalah, sebagai wujud implementasi kebiasaan dalam inkuiri dan eksplorasi matematika, serta memiliki rasa ingin tahu, semangat belajar yang kontinu, percaya diri, dan ketertarikan pada matematika melalui pengalaman belajar (Kemendikbud, 2016: 111). Ketentuan Permendikbud tersebut secara jelas memberikan gambaran bahwa model pembelajaran yang dituntut dalam pembelajaran matematika adalah kebiasaan ber-inkuiri dan ber-eksplorasi matematika. Maknanya adalah bahwa keberhasilan pembelajaran matematika ditentukan oleh seberapa mampu seorang guru merancang pembelajarannya supaya para siswa memiliki pengalaman ber-inkuiri dan ber-eksplorasi, sehingga timbul sikap positif bermatematika. 
Guru profesional merupakan faktor penentu proses pendidikan yang berkualitas (Rusman 2012: 19). Dalam pembelajaran guru tidak hanya berfungsi mentransfer pengetahuan saja tetapi juga bertugas untuk memberikan keterampilan, merubah perilaku peserta didik (Astuti, Slameto dan Dwikurnaningsih, 2016: 117). Lebih lanjut Lampiran Permendikbud No. 21 Tahun 2016 tentang Standar Isi Pendidikan Dasar Dan Menengah menyatakan matematika merupakan ilmu yang mendasari perkembangan teknologi dimana mempunyai peran yang sangat penting dalam berbagai displin ilmu yang berfungsi untuk memajukan daya pikir manusia yang diperoleh dari pegalaman atau diperoleh dari benda yang konkrit. Mujis dan Reynolds (2008: 332) mengatakan bahwa matematika dianggap pelajaran yang sulit dan kurang menyenangan bagi peserta didik maupun orang dewasa. Sedangkan menurut Hanisah, S, Tri, dan Setyo (2014: 1) menyatakan bahwa matematika mengajarkan agar peserta didik mampu berfikir kritis dan mengambil keputusan secara rasional.

Mengacu batasan yang dikemukakan Kemendikbud, Mujis dan Reynolds serta Hanisah, S, Tri, dan Setyo tersebut di atas, dapat dirumuskan secara sederhana bahwa hakikat matematika adalah kajian yang berisi tentang bagaimana mengajarkan bilangan; geometri; dan statistika agar peserta didik mampu berfikir kritis dan mengambil keputusan secara rasional, cermat dan teliti, jujur, bertanggung jawab, dan tidak mudah menyerah dalam menyelesaikan masalah, sebagai wujud implementasi kebiasaan dalam inkuiri dan eksplorasi matematika, serta memiliki rasa ingin tahu, semangat belajar yang kontinu, percaya diri, dan senang. Meskipun Mujis dan Reynolds mengatakan bahwa matematika dianggap pelajaran yang sulit dan kurang menyenangan, bukan berarti para guru menyerah dengan pandangan seperti ini. Tidak dipungkiri bahwa matematika digambarkan sebagai salah satu pelajaran yang menjadi momok bagi siswa. Siswa menganggap bahwa matematika adalah pelajaran yang mempunyai faktor kesulitan yang tinggi, karena siswa harus terampil dalam operasi hitung (penjumlahan, perkalian dan pembagian). Padahal, matematika adalah ilmu pasti, pelajaran matemtaika lebih mengajarkan rumus dimana hasilnya pasti. Contohnya saja dalam pelajaran matematika mengajarkan hasil penjumlahan, pengurangan perkalian dan pembagian dimana perosalan tersebut berhubungan dengan kehidupan sehari hari. Pemecahan masalah harus dilakukan dengan penelitian yang logis dan sistematis.

Dalam rangka menumbuhkan keterampilan berpikir kritis tersebut di atas, membelajarkan matematika tidak bisa dilakukan dengan cara metode ceramah saja melainkan dengan memilih dan memilah mana-mana model pembelajaran yang memiliki potensi menumbuhkan keterampilan berpikir kritis tersebut. Tingkat keterampilan berpikir kritis ini diyakini akan menumbuhkan pula hasil belajar yang lebih tinggi (Husnah, 2017: 10; Wicaksono, 2014: 1). Berbagai tipe model pembelajaran kooperatif yang mampu menumbuhkan keterampilan berpiki kritis yaitu Numbered Head Together (NHT), Student Team Achievement Division (STAD), Pendekatan Struktural yang meliputi Think Pair Share (TPS) dan Investigasi Kelompok atau Team Game Tournament (TGT). Model-model 
pembelajaran kooperatif tipe NHT, STAD, TPS maupun TGT merupakan model universal yang dapat diterapkan untuk berbagai muatan matapelajaran, termasuk matematika. Kadar potensi masing-masing tipe model pembelajaran, tentu saja tergantung karakteristik materi pelajarannya (Trianto, 2009: 59). Dari berbagai model tersebut, model yang paling berpotensi untuk menumbuhkan keterampilan berpikir kritis adalah model STAD. Pembelajaran dengan model STAD dapat memberikan peluang kepada siswa untuk saling bertukar pikiran atau pendapat dan mencari jawaban yang paling tepat secara kolaboratif. Dalam hal ini, siswa aktif dalam memecahkan soal yang diberikan guru (Huda, 2013: 203). Mengingat bahwa model STAD tersebut berpotensi dalam menumbuhkan keterampilan berpikir kritis dan hasil belajar, maka para guru semestinya dapat berlatih unutuk menerapkannya.Dalam hal ini para guru dapat memberdayakan diri melalui workshop, pelatihan-pelatihan di lingkup MGMP, maupun KKG. Namun tidak jarang upaya-upaya tersebut belum sepenuhnya memberikan hasil yang memuaskan.

Hasil studi pendahuluan yang dilaksanakan penulis pada bulan Oktober 2017 di SDN Tingkir Lor 02 Salatiga khususnya mata pelajaran matematika kelas 5 di peroleh data skor keterampilan critical thinking siswa. Dari satu kelas yang berjumlah 31 siswa hanya siswa 5 siswa (16\%) yang kemapuan berpikir kritisnya Tinggi, sementara 8 siswa (25\%) untuk kategori cukup dan 18 siswa (59\%) yang masih dalam kategori rendah. Hasil pengukuran awal keterampilan berpikir kritis tersebut, nampaknya berkorelasi dengan capaian hasil belajarnya. Data hasil belajar siswa dapat dikatakan kurang maksimal karena masih banyak siswa yang mendapatkan nilai dibawah KKM. Dari hasil studi dokumen nilai siswa terdapat 18 (58\%) dari 31 siswa yang mendapat nilai di bawah KKM (70). Capaian rerata hasil belajarnyapun masih rendah yaitu 52 untuk muatan pelajaran matematika.

Hasil observasi kelas terhadap pembelajaran di SD Negeri Tingkir Lor 02 Salatiga, guru sudah menerapakan model pembelajaran yang menyenangkan, menarik untuk menarik antusias belajar siswa terhadap materi pembelajaran. Suasana kelas dengan jumlah siswa sebanyak 30, dengan berbagai karakter yang berbeda nampaknya menjadikan kelas kurang kondusif. Suasana ini diduga dipengaruhi juga oleh metode pembelajaran yang digunakan, yaitu ceramah. Pembelajaran terpaku pada guru dan buku sehingga membuat siswa kurang percaya diri dengan jawaban yang ditemukan. Pilihan pendekatan dan model pembelajaran yang cenderung teacher centered, menjadikan pembelajaran kurang memancing siswa untuk mengembangkan kemampuan berfikir kritis. Apalagi guru sering menggunakan teknik menghafal, sehingga pembelajaran kurang menarik dan membosankan bagi siswa, yang akhirnya akan berdampak pada rendahnya berpikir kritis yang berdampak pula pada hasil belajar siswa.

Berpijak pada hasi studi pendahuluan dan hasi observasi seperti telah dipaparkan di atas, ada beberapa permasalahan dalam pembelajaran matematika di SDN Tingkir Lor 2 Salatiga. Permasalahan berawal dari pilihan pendekatan pembelajaran yang bersifat teacher centered dan pilihan metode ceramah menimbulkan dampak kurang kondusifnya suasana pembelajaran. Akibatnya pembelajaran kurang menarik dan membosankan bagi siswa, dampak lanjutannya 
adalah kurang berkembangnya keterampilan berpikir kritis siswa dan berujung pada hasil belajar yang masih rendah seperti teah dipaparkan di atas. Perolehan hasil belajar jauh dari target pencapaian KKM 75\% siswa mencapai KKM (70).

Dalam rangka mengatasi permasalahan pembelajaran ini, penulis berdiskusi dengan guru kelas untuk mencari cara pemecahannya. Secara teoretik, ada berbagai model pembelajaran kooperatif yang mampu menciptakan suasana pembelajaran di kelas lebih kondusif dan antusias, yang nantinya akan berdampak pada meningkatnya keterampilan berpikir dan hasil belajar siswa, salah satunya adalah model pembelajaran STAD. Model kooperatif ini berfungsi untuk membentuk sebuah hubungan antar peserta didik dan guru dengan peserta didik sehingga pembelajaran berlangsung efektif (Trianto, 2009: 59; Huda, 2013: 203). Sebagai rumpun model pembelajaran kooperatif, ciri khas model ini bersifat kolaboratif. Rusman (2010: 203) berpendapat bahwa model pembelajaran kooperatif memiliki ciri khusus, yaitu potensinya untuk membangun suasana kelas lebih antusias dan mendorong siswa untuk berpartisispasi dalam kelompokkelompok kecil. Sedangkan Isjoni (2013: 16) menyatakan pembelajaran kooperatif adalah pembelajaran yang mengajak siswa untuk belajar bekelompok kecil (4-6) siswa untuk mencapai tujuan bersama.

Implementasi model STAD ini siswa dibagi menjadi kelompok yang beranggotakan 4-6 yang beragam kemampuan, jenis kelamin, suku, ras, agama dan tingkat kemampuan akademik. Kemudian setiap kelompok mendapat tugas masing-masing. Model ini juga dapat divariasi dengan metode ceramah, tanya jawab dan diskusi (Trianto (2007: 133). Selanjutnya menurut Isjoni (2007: 70) menjelaskan STAD dapat digunakan dalam berbagai bidang ilmu, misalnya Matematika, Ilmu Pengetahuan Sosial, Ilmu Pengetahuan Alam, dan digunakan pada berbagai jenjang pendidikan dari sekolah dasar sampai perguruan tinggi. Kelebihan dari model STAD ini adalah siswa saling bekerja sama dalam memecahkan masalah pembelajaran dengan cara saling berinteraksi antara satu dengan yang lain sehingga yang tadinya kurang bisa memecahkan akan dapat menyelesaikannya. Hal ini tentu akan berdampak dalam berfikir kritis yang akan meningkatkan hasil belajar siswa.

Joyce, Weil dan Calhoun (2009: 104-106) menyatakan bahwa setiap model pembelajaran mengandung beberapa unsur yaitu, sintakmatik (tahap-tahap kegiatan), sisem sosial (situasi atau suasana), prinsip reaksi (perilaku guru terhadap siswa), sistem pendukung (sarana dan alat), dan dampak insruksional dan pengiring. Sintak atau langkah-langkah STAD mencakup: 1) tahap presentasi kelas; 2) kerja tim; 3) kuis; 4) pemberian skor; dan 5) pemberian penghargaan (Purwati, 2010: 111; Sharan, 2012: 9-11). Sistem sosial berupa penumbuhan kerja tim dan bertukar pikiran secara kritis. Prinsip reaksi berupa peran guru sebagai fasilitator, pendamping belajar dan pemberi skor. Sistem pendukung yang perlu disiapkan berupa lembar materi, LKS dan hadiah sebagai penghargaan atas capaian belajar siswa. Dampak instruksional berkaitan dengan indikator pencapaian hasil belajar yang telah dituangkan dalam RPP tentang materi 
pecahan, sedangkan dampak pengiring diantaranya adalah kerjasama tim dan keterampilan berpikir kritis.

Tentang berpikir kritis, Ennis "...critical thinking is reasonable, reflective thinking that is focused on deciding what to believe or do" (dalam Zubaidah, 2015: 207). Pandangan lain bahwa berpikir kritis adalah aktivitas mental seseorang berupa proses bernalar dan berefleksi dalam rangka membuat keputusan atau memecahkan masalah (Zubaidah, 2017: 3). Menurut Partnership for $21^{\text {st }}$ Century Skills (2014), berpikir kritis menjadi salah satu dari beberapa keterampilan yang dibutuhkan untuk menyiapkan siswa agar berprestasi dalam melanjutkan ke jenjang pendidikan yang lebih tinggi atau ke dunia kerja.

Berbagai penelitian terdahulu tentang keterampilan berpikir kritis dan hasil belajar ini antara lain telah dilakukan oleh Najmina (2017); Husnah (2017); Sihaloho (2017) yang menemukan bahwa ternyata pembelajaran inovatif (termasuk STAD) dapat menumbuhkan keterampilan berpikir kritis dan sekaligus berhubungan positif signifikan dengan hasil belajar siswa. Maknanya bahwa peningkatan skor keterampilan berpikir kritis diikuti oleh peningkatan hasil belajar. Hasil penelitian tentang model STAD juga telah banyak dilakukan, diantaranya penelitian Nuraini Sofiatin , (2015); Iffah, N. (2017); Rais, H. (2015) menemukan bahwa implementasi model pembelajaran STAD efektif untuk mencapai hasil belajar matematika. Berbagai penelitian PTK di SD tentang penerapan STAD juga mendukung penelitian ini, misalnya penelitian Rahmawati, (2015); Rosa Salenika (2016); Yoyok Eko Prasetyono (2015); Sumur, I. (2016) menemukan bahwa model STAD meningkatkan hasil belajar matematika siswa SD.

Berdasarkan latarbelakang permasalahan, studi pendahuluan, hakikat STAD dan berbagai penelitian terdahulu seperti telah dipaparkan di atas, mendorong penulis untuk melakukan penelitian tentang implementasi model pembelajaran $S T A D$, dengan permasalahan berikut: 1) apakah keterampilan berpikir kritis siswa kelas IV SDN Tingkir Lor 2 Salatiga dapat ditingkatkan melalui model pembelajaran $S T A D$ ?; 2) apakah penerapan model STAD dapat meningkatkan persentase jumlah ketuntasan hasil belajar pada siswa SDN Tingkir Lor 02 Salatiga?

\section{METODE PENELITIAN}

Penelitian ini dilaksanakan di kelas 5 SD N Tingkir Lor 02 Salatiga dengan jumlah 31 siswa. Penelitian ini menggunakan jenis Penelitian Tindikan Kelas yang terdiri dari siklu I dan siklus II. Model PTK menggunakan model spiral dari C. Kemmis dan Mc.Taggart yaitu terdiri dari tiga tahap yaitu: 1) perencanaan (planning); 2) pelaksanaan dan pengamatan (acting and observasing); dan 3) refleksi (reflecting). Kompetensi dasar yang akan dicapai dalam pembelajaran ini adalah KD 3.1. Menjelaskan dan melakukan penjumlahan dan menarik dua pecahan dengan penyebut yang berbeda (untuk siklus I), serta KD 3.2 Menjelaskan dan melakukan perkalian dan pembagian pecahan dan decimal untuk siklus II.

Setiap siklus dimulai dengan perencanangan yaitu dengan merancang rencana pelaksanaan pembelajaran (RPP) kemudian tahap pelaksanaan hingga tahap refleksi berdasarkan hasil evaluasi terhadap pembelajaran yang telah 
dilakukan. Dalam menyusun rencana pelaksanaan pembelajaran (RPP) terdapat langkah-langkah yang meliputi pemahaman khusus terhadap karakteristik peserta didik, menyesuaikan materi dengan model pembelajarann. Selanjutnya membuat alat peraga atau memanfaatkan media belajar yang diperlukan atau sesuai dengan memperhatikan karakteristik peserta didik, setelah itu masuk ke dalam tahap penyusunan rencana kegiatan belajar yang dilakukan oleh guru dan peserta dididk dan kemudian RPP yang telah sudah disusun diaplikasikan dengan memperhatikan kesesuaian antara peserta didik, materi, sarana dan prasarana serta alokasi waktu saat mengajar.

Instrumen pengumpulan data dalam penelitian ini menggunakan instrument lembar angket berpikir kritis yang teruji reliabilitas dan validitasnya. Instrumen untuk mengukur hasil belajar matematika menggunakan soal tes yang terdiri atas 15 butir yang telah diuji cobakan dan diolah dengan menggunakan Anates. Teknik analisis data menggunakan teknik deskriptif kategoris dan komparatif.

\section{HASIL PENELITIAN DAN PEMBAHASAN}

\section{Hasil Penelitian}

Implementasi pembelajaran menggunakan model pembelajaran STAD dalam penelitian ini berlangsung selama 2 siklus. Setelah dilakukan pengukuran terhadap tingkat keterampilan berpikir kritis siswa, diperoleh data seperti tertuang dalam tabel 1, dan 2 berikut.

Tabel 1. Statistik Deskriptif Tingkat Keterampilan Berpikir Kritis Siklus I dan II

\begin{tabular}{lcccc}
\hline \multicolumn{1}{c}{ Skor stiap Siklus } & N & Minimum & Maximum & Mean \\
\hline $\begin{array}{l}\text { Skor Keterampilan } \\
\text { Berpikir Kritis Siklus I }\end{array}$ & 31 & 41 & 78 & 58,23 \\
\hline $\begin{array}{l}\text { Skor Keterampilan } \\
\text { Berpikir Kritis Siklus II }\end{array}$ & 31 & 63 & 93 & 77,55 \\
\hline
\end{tabular}

Tabel 1 di atas memberikan gambaran bahwa skor terendah keterampilan berpikir kritis siswa pada siklus I adalah 41, skor tertinggi 78 dengan rerata 58, 23. Pada siklus II, skor terendah 63, tertinggi 93, dan rerata 77,55. Berdasarkan data tersebut, nampak terjadi kenaikan yang signifikan. Selisih kenaikan skor terendah dari siklus I ke siklus II mencapai 22 poin. Selisih kenaikan skor tertinggi dari siklus I ke siklus II mencapai 15 poin. Demikian juga selisih reratanya juga terpaut jauh, yaitu 19,32 poin. Peningkatan rerata tingkat keterampilan berpikir kritis mencapai 33. $1 \%$.

Tabel 2. Distrubusi Frekuensi Keterampilan Berpikir Kritis Siswa Siklus I dan II

\begin{tabular}{clcccccc}
\hline \multicolumn{4}{c}{ Siklus I } & & \multicolumn{3}{l}{ Siklus II } \\
\hline $\begin{array}{c}\text { Rentang } \\
\text { Skor }\end{array}$ & N & Kategori & $\%$ & $\begin{array}{c}\text { Rentang } \\
\text { Skor }\end{array}$ & N & Kategori & $\%$ \\
\hline
\end{tabular}




\begin{tabular}{cccccccc}
\hline \hline \multicolumn{10}{c}{} & 13 & Rendah & $42 \%$ & 51 & 0 & Rendah & 0 \\
$52-65$ & 11 & Cukup & $35 \%$ & $52-65$ & 3 & Cukup & $10 \%$ \\
$66-79$ & 7 & Tinggi & $23 \%$ & $66-79$ & 16 & Tinggi & $50 \%$ \\
$\geq 80$ & 0 & Sangat & 0 & $\geq 80$ & 12 & Sangat & $40 \%$ \\
& & Tinggi & & & & Tinggi & \\
\hline
\end{tabular}

Komparasi data distribusi frekuensi pada tabel 2 di atas menunjukkan bahwa pada pembelajaran siklus I, terdapat 13 siswa (42\%) berada pada kategori rendah, 11 siswa $(35 \%)$ berada pada kategori cukup, 7 orang siswa $(23 \%)$ berada pada kategori tinggi, dan tak seorang siswapun berada pada kategori sangat tinggi. Hal ini berbeda dengan data pada siklus II. Nampak bahwa tak seorang siswapun berada pada kategori rendah, terdapat 3 siswa (10\%) mencapai kategori cukup, 16 siswa (50\%) mencapai kategori tinggi, dan 12 siswa (40\%) berada pada kategori sangat tinggi. Data distribusi frekuensi kategoris pencapaian tingkat keterampilan berpikir kritis ini menunjukkan kenaikan yang cukut tinggi.

Hasil pengukuran tingkat pencapaian hasil belajar pada siklus I dan II setelah dilakukan tindakan penerapan model pembelajaran STAD dipaparkan pada tabel 3 berikut. Seperti telah dikemukakan pada bagain pendahuluan, bahwa ukuran kenaikan hasil belajar dilihat berdasarkan persentase jumlah siswa yang mencapai ketuntasan belajar (KKM). Pada tabel 3, dengan batas tuntas sebesar 70, pada siklus I diperoleh data 19 siswa (61\%) mencapai KKM, 12 siswa (39\%) belum mencapai KKM. Pada siklus II terdapat 26 siswa (84\%) mencapai KKM, hanya 5 siswa (16\%) yang belum mencapai KKM. Data ini menunjukkan peningkatan persentase jumlah siswa yang mencapai KKM sebesar 37,7\%. Artinya ada peningkatan yang cukup tinggi.

Tabel 3. Komparasi Hasil Hasil Belajar Siswa Siklus I dan II

\begin{tabular}{llcccc}
\hline \multirow{2}{*}{ Skor } & \multicolumn{1}{|c}{ Ketuntasan } & \multicolumn{2}{c}{ Siklus I } & \multicolumn{2}{c}{ Siklus II } \\
\cline { 3 - 6 } & Frekuensi & \% & Frekuensi & \% \\
\hline$\geq 70$ & Banyak siswa yang tuntas & 19 siswa & $61 \%$ & 26 & $84 \%$ \\
570 & $\begin{array}{l}\text { Banyak siswa tidak } \\
\text { tuntas }\end{array}$ & 12 siswa & $39 \%$ & 5 & $16 \%$ \\
\hline
\end{tabular}

\section{Pembahasan}

Berpijak pada dua permasalahan yang menjadi acuan penelitian ini, yaitu apakah keterampilan berpikir kritis siswa dapat ditingkatkan melalui model pembelajaran STAD dan apakah penerapan model STAD dapat meningkatkan persentase jumlah ketuntasan hasil belajar siswa, keduanya terbukti dapat meningkat. Persentasi peningkatan rerata skor keterampilan berpikir kritis dari siklus I ke siklus II mencapai $33.1 \%$. Angka ini hampir sepertiga kali dari perolehan siklus I. Demikian juga persentase peningkatan rerata tingkat hasil belajar siswa dari siklus I ke siklus II mencapai 37, 7\%. Dengan demikian penelitian tindakan kelas ini dikatakan berhasil pada siklus ke II. Temuan lain, meskipun bukan permasalahan penelitian, nampak bahwa kedua varibel berkorelasi secara signifikan dengan koefisien korelasi mendekati 1.0. 
Temuan hasil penelitian dan keberhasilan penelitian ini terjadi oleh karena sintak pembelajaran $S T A D$, yaitu tahap presentasi kelas; kerja tim; pemberian kuis; pemberian skor; dan pemberian penghargaan (Purwati, 2010: 111; Sharan, 2012: 9-11), dilakukan secara konsistem dalam pembelajaran siklus ke II. Tahap presentasi kelas yang dilakukan guru dan harus dicermati sungguh-sunguh oleh siswa, oleh karena siswa harus menjawab kuis berdasarkan penjelasan guru, membuat siswa benar-benar memahami materi penjumlahan dan menarik dua pecahan dengan penyebut yang berbeda serta perkalian dan pembagian pecahan dan desimal. Pada tahap kerja tim, oleh karena saling berbagi pengetahuan menjadikan para siswa secara tidak disadarinya menguasai materi lebih baik, sehingga pada tahap dilakukan kuis, mereka bisa mengerjakan dengan baik. Kemudian pada tahap pemberian skor dan pemberian penghargaan, nampaknya tahapan ini mendorong siswa untuk berlomba-lomba menjadi yang terbaik. Sama halnya dengan keberhasilan dalam peningkatan hasil belajar, peningkatan keterampilan berpikir kritis juga disebabkan oleh keberhasilan menerapkan pembelajaran $S T A D$. Konsep berpikir kritis seperti telah dipaparkan pada bagian pendahuluan, merupakan aktivitas mental seseorang berupa proses bernalar dan berefleksi dalam rangka membuat keputusan atau memecahkan masalah (Zubaidah, 2017: 3), terjadi karena mereka berdiskusi mencari solusi terbaik untuk memecahkan masalah; disinilah terjadi proses berpikir kritis atau bernalar.

Keberhasilan penerapan STAD ini ini sejalan dengan berbagai penelitian yang telah dilakukan terlebih dahulu, sehingga penelitian ini mengukuhkan temuan penelitian sejenis. Temuan bahwa kedua varibel berkorelasi secara signifikan dengan koefisien korelasi mendekati 1.0, sejalan dengan penelitian yang dilakukan Najmina (2017); Husnah (2017); Sihaloho (2017) yang menemukan bahwa tingkat keterampilan berpikir kritis berhubungan positif signifikan dengan hasil belajar siswa. Kesuksesan penerapan sintak pembelajaran STAD, sehingga dapat meningkatkan hasil belajar siswa sejalan dengan hasil penelitian Nuraini Sofiatin, (2015); Iffah, N. (2017); Rais, H. (2015) menemukan bahwa implementasi model pembelajaran STAD efektif untuk mencapai hasil belajar matematika. Demikian juga temuan penelitian PTK di SDN Tingkir Lor 02 ini sejalan dengan penelitian PTK sejenis yang dilakukan di berbagai sekolah dasar, diantaranya penelitian Rahmawati, (2015); Rosa Salenika (2016); Yoyok Eko Prasetyono (2015); Sumur, I. (2016) yang menemukan menemukan bahwa model STAD meningkatkan hasil belajar matematika siswa SD.

\section{SIMPULAN DAN SARAN Simpulan}

Berdasarkan hasil penelitian dan pembahasan, maka dapat disimpulkan bahwa implementasi model pembelajaran STAD dapat meningkatkan keterampilan berpikir kritis dan hasil belajar siswa kelas 5 SDN Tingkir Lor 02 Salatiga. Peningkatan keterampilan berpikir kritis dapat dilihat dari rerata skor pada siklus I sebesar 58, berada pada kategori cukup, kemudian meningkat menjadi 77 berada pada kategori tinggi pada siklus II. Peningkatan hasil belajar 
dapat dilihat dari perolehan skor pada siklus I sebesar 66, dengan persentase ketuntasan belajar sebesar $61 \%$, meningkat menjadi 80 , dengan persentase ketuntasan belajar mencapai $84 \%$ pada siklus II.

Saran

Berpijak pada simpulan penelitian ini bahwa implementasi model pembelajaran STAD dapat meningkatkan keterampilan berpikir dan hasil belajar siswa, maka disarankan agar guru SDN Tingkir Lor 2 Salatiga sering menggunakan model STAD ini. Saran tambahan bahwa guru harus benar-benar fokus untuk membentuk kelompok secara heterogen untuk menghindari adanya kegaduhan setiap kelompok.

\section{DAFTAR PUSTAKA}

Astuti, Suhandi, Slameto, Dwikurnaningsih, Yari. (2017). Peningatan Kemampuan Guru Sekolah Dasar Dalam Penyusunan Instrumen Ranah Sikap Melalui in House Training. Kelola: Jurnal Manajamen Pendidikan , 4 (1) 37- 47.

Hanisah, S, Tri, dan Setyo (2014). Penggunaan Model Pembelajaran Kooperatif Tipe Group Investigation Dalam Peningkatan Pembelajaran Matematika Tentang Pecahan Pada Siswa Kelas V SD. Kalam Cendekia, $2(2), 1-7$.

Huda, Miftahul. (2013). Model- Model Pengajaran dan Pembelajaran. Yogyakarta : Pustaka Pelajar.

Husnah, M. (2017). Hubungan Tingkat Berpikir Kritis Terhadap Hasil Belajar Fisika Siswa Dengan Menerapkan Model Pembelajaran Problem Based Learning. PASCAL Journal of Physics and Science Learning), 1(2).

Iffah, N. (2017). The Implementation of Cooperative Model of Missoury Type of Modified Mathematics Project Concerning Cognitive Style (Experiment Study On Lines and Angles Material of Class VII at MTS Muallimin Muhammadiyah in Makassar. Daya Matematis: Jurnal Inovasi Pendidikan Matematika, 4(2), 173-185.

Joyce, B; Weil, M., \& Calhoun, E. (2009). Models of Teaching: Model-Model Pengajaran.Yogyakarta: Pustaka Pelajar.

Kemendikbud.(2016). Permendikbud No. 24 Tahun 2016 tentang Kompetensi Inti dan Kompetensi Dasar. Jakarta: Direktur Jenderal Peraturan PerundangUndangan Kementerian Hukum dan Hak Asasi Manusia Republik Indonesia.

Kemendikbud.(2016). Permendikbud No. 21 Tahun 2016 tentang Standar Isi Pendidikan Dasar dan Menengah. Jakarta: Direktur Jenderal Peraturan Perundang-Undangan Kementerian Hukum dan Hak Asasi Manusia Republik Indonesia.

Muijis dan Reynadoys , (2008). Effective Teaching (Teori dan Aplikasi). Yogyakarta : Pustaka Belajar.

Nurhasanah, S. (2010). Penerapan Model Pembelajaran Kooperatif Tipe STAD Untuk Meningkatkan Pemahaman Peristiwa Proklamasi Indonesia Dalam Pelajaran IPS Pada Siswa Kelas V SD Negeri 01 Pereng Karanganyar 
Tahun Pelajaran 2009/2010 (Doctoral dissertation, Universitas Sebelas Maret).

Najmina, Nana (2017) Meningkatkan Sikap Berpikir Kritis dan Hasil Belajar Siswa Melalui Model Cooperatif Learning Tipe Group Investigation dalam Mata Pelajaran PPKn. In: Konferensi Nasional Kewarganegaraan III, 11 November 2017, Yogyakarta, Indonesia.

Partnership for $21^{\text {st }}$ Century Learning (2014). Preparing 21st Century Students for a Global Society: An Educator's Guide to the "Four Cs". National Education Association.

Rahmawati, Nanik (2015). Meningkatkan Aktivitas Dan Hasil Belajar Melaluimodel Stad Berbantuan "Kartupinus" Materi Bilangan Bulat Siswa Kelas Iv Sd Negeri Dukuhbangsa 02 Kabupaten Tegal. (Doctoral Dissertation FKIP-UNNES)

Rusman,(2012). Model-Model Pembelajaran. Bandung : PT Rajagrafindo Persada.

Rusman,(2011). Model-Model Pembelajaran Mengembangkan profesionalitas guru .Bandung : PT Rajagrafindo Persada.

Rais, H. (2015). Comparison Of The Effectiveness of Cooperative Model of STAD Type and Problem-Based Learning Model With Scientific Approach On Sequence And Series Lesson Material In Class X IPA AT SMAN 1 Duampanua. Daya Matematis: Jurnal Inovasi Pendidikan Matematika, 3(2), 221-233.

Rosa Selenika. (2016). Keefektifan Model Kooperatif Tipe Student Teams Achievement Division Terhadap Aktivitas Dan Hasil Belajar SBK Materi Ansambel Musik Siswa Kelas V SD Negeri Manyaran 01 Kota Semarang. Skripsi. Semarang: Universitas Negeri Semarang.

Sofiatin , Nuraini. (2015). Penerapan Student Teams Achievement Divisions Berbantuan Media Audiovisual Untuk Meningkatkan Kualitas Pembelajaran Peduli Terhadap Makhluk Hidup Kelas Iva Sdn Tawang Mas 01 Semarang. (Doctoral Dissertation FKIP-UNNES).

Susanto, Ahmad. (2013). Teori Belajar dan Pembelajaran di Sekolah Dasar. Jakarta: Kencana.

Sihaloho, F. A. S. (2017, April). Hubungan Kemampuan Berpikir Kritis Dan Soft Skills Dengan Prestasi Belajar Siswa Pada Mata Pelajaran Ekonomi Kelas XI SMAN 1 Labuhan Deli TP 2015/2016. In Prosiding Seminar Pendidikan Ekonomi dan Bisnis (Vol. 3, No. 1).

Trianto. 2009. Mendesain Model Pembelajaran Inovatif-Progresif. Surabaya: Kencana

Wicaksono, A. G. C. (2014). Hubungan Keterampilan Metakognitif dan Berpikir Kritis terhadap Hasil Belajar Kognitif Siswa SMA pada Pembelajaran Biologi dengan Strategi Reciprocal Teaching di Kabupaten Malang. DISERTASI dan TESIS Program Pascasarjana UM.

Yoyok Eko Prasetyono. (2015). Penerapan Model Student Teams Achievement Division Berbasis Media Visual Untuk Meningkatkan Kualitas 
Pembelajaran IPS Siswa Kelas V SDN Gunungpati 01 Kota Semarang. Under Graduates Thesis, Universitas Negeri Semarang.

Zubaidah, S. (2015, April). Asesmen Berpikir Kritis Terintegrasi Tes Essay. In Prosiding Symposium on Biology Education (Symbion) (pp. 200-209).

Zubaidah, S., \& UM, J. B. F. U. N. M. (2017). Pembelajaran Kontekstual Berbasis Pemecahan Masalah untuk Mengembangkan Kemampuan Berpikir Kritis. In Makalah disampaikan pada Seminar Nasional dengan tema Inovasi Pembelajaran Berbasis pemecahan Masalah dalam Pembelajaran Biologi di Universitas Muhammadiyah Makasar, Makasar (Vol. 6) 